\title{
LINGUISTIC AND ETHNOCULTURAL DYNAMICS OF TRADITIONAL AND NON-TRADITIONAL VALUES IN THE SLAVIC WORLD
}

\author{
TATYANA ALEKSANDROVA \\ INSTITUTE FOR BULGARIAN LANGUAGE PROF. LYUBOMIR ANDREYCHIN, \\ BULGARIAN ACADEMY OF SCIENCES \\ t_alexandrova_@mail.bg
}

Issue 1/2019 of Balgarski ezik features 4 papers which present results from the international project Linguistic and Ethnocultural Dynamics of Traditional and Non-traditional Values in the Slavic World), LED-SW (ERA.NET RUS Plus; RUS_ST 2017-472). The aim of the project is a multi-dimensional study of the commonalities and differences in the traditional and non-traditional values and their dynamics in the Bulgarian, Slovak and Russian culture through linguistic, textological, linguo-cultural and interdisciplinary analysis based on linguistic, folklore and historical sources. The studies represent a contribution to Bulgarian and Slavic linguistics.

In his paper The Language of Byzantine-Slavic Written Culture in Slovakia from an Axiological Point of View Peter Žeňuch discusses the linguistic peculiarities of a unique body of written monuments - texts written in Cyrillic which exist and function in a Slovakian setting. The basis for the creation of these texts is the language of the religion, which in the case of Slovak believers of the Byzantine rite is the Church Slavonic language.

In her article titled Bravery as a Value in the History of the Bulgarian Literary Language, Vanya Micheva discusses the linguistic representations of the concept of bravery on the basis of the contrastive analysis of language data from Old Bulgarian classical works from the $9^{\text {th }}-11^{\text {th }}$ century, original writings by Patriarch Euthymius from the $14^{\text {th }}$ century and New Bulgarian damaskins from the $17^{\text {th }}$ century. Kalina Micheva's paper Axiological Aspects of the Concept of Love studies the linguistic aspects of the concept of love and its functioning in various contexts in the traditional Bulgarian culture and the history of Bulgarian through linguistic and axiological analysis of Old Bulgarian manuscripts from the $9^{\text {th }}-11^{\text {th }}$ and Bulgarian proverbs.

In his paper Forms and Projections of Word Magic as a Cultural Value in Folk Prose Lubomír Gábor deals with the forms, functions and meaning of the magic of words in oral folklore, and in Slovak fairy tales, in particular. The au- 
thor interprets the role of word magic in an anthropological perspective and discusses its projection in the cultural memory of human societies.

Iliana Genew-Puhalewa's study titled Axiologisation of Contemporary Concepts and Terms - on the Example of Climate is another study within the conceptual framework of axiology. The author discusses lexical units in the thematic domain of 'environment' as an illustration of the axiologisation of terms in Bulgarian. She goes on to emphasise the global nature of the studied processes and motivates the necessity for updating the lexicographic description of terms with respect to current changes in their semantics.

The issue features the first part of a study by Ignacy Doliński titled Categories and Word Formation Paraphrases of Derivatives Referring to Means of Activity (NInstr): the Example of Bulgarian Words Formed with the -a/-я Suffix. The author proposes an extension to the authoritative study of the word-formation category of nomina instrumenti published in the $9^{\text {th }}$ volume of Gramatyka konfrontatywna butgarsko-polska (Bulgarian-Polish Contrastive Grammar) by broadening the scope of this category and adding new semantic roles. He presents a more detailed classification which includes groups that may be described by means of more rigid construction of word formation paraphrases. The conclusions are supported with examples from one group of Bulgarian words for means of activities (NInstr) - feminine derivatives with the $-a /-я$ suffix.

The last paper titled Current State of the Bulgarian-English Parallel Corpus with Aligned Verb Forms is authored by Todor Lazarov. The paper describes the purpose of the construction of this corpus in the context of contemporary theory and practice, its features and structural characteristics. Examples of primary language data derived from the corpus are presented as well.

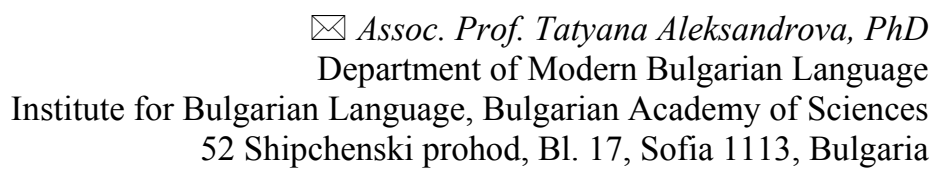

Published: 31 March 2019 